\title{
A CONCEPTUAL PAPER OF SPIRITUAL TOURISM MODEL (ISTOM)
}

\author{
Siti Salwa Md Sawari', Zaleha Mohamad ${ }^{2}$, Nor'ain Othman ${ }^{3}$ \& Amirul Eimer Ramdzan Ali $^{4}$ \\ ${ }^{1,2}$ Faculty of Business, Economics and Social Development, University of Malaysia Terengganu \\ ${ }^{3}$ Faculty of Hotel and Tourism Management, Universiti Teknologi MARA \\ ${ }^{4}$ Kulliyyah of Languages and Management, International Islamic University Malaysia \\ (p4677@pps.umt.edu.my, zaleha.m@umt.edu.my, ainothman@uitm.edu.my, dral@iium.edu.my)
}

\begin{abstract}
Spiritual tourism also known as one type of special interest tourism activity based on the expectations related with spirituality is now continuously developing and is being demanded by tourists. This demand is in line with the improvement of tourist information technology. Spiritual tourism will continuously develop due to the changes in the needs of the market. Initially, spiritual activities are directly connected with religion, and they have now shifted to the idea to something that is related with spiritual activities which include, creating comfort, pleasure and quality experience. Despite of the rapid development, it can be seen in the academic writing research, in which, there are still several researchers who argued religious and spiritual tourism as the same type of tourism. The phenomenon of religious spiritual tourism is more complex in the modern era and has been recognised as a separate tourism. Internationalising religious spiritual tourism in the context of people, places, and events has become a challenge. Religious spiritual tourism requires a new mode as a form of quality tourism development so that it will organise sociocultural life with varieties of unique customs and become a tool to increase regional income, creating job opportunities and indirectly improve Malaysians' quality of life. Thus, there is an urge to integrate the religious aspect into spiritual tourism. Hence, this research aims to develop an Islamic Spiritual Tourism Model (ISToM) based on Maqasid As Shariah. It is hoped that the findings will contribute to the existing knowledge about values and provide implications for developing spiritual tourism sustainably.
\end{abstract}

KEYWORDS: Spiritual Tourism; Islamic Tourism; Islam; Religious Tourism

\section{PURPOSE AND BACKGROUND}

Spiritual tourism also known as special interest tourism based on the expectations related with spirituality is now developing and in demand by tourists. This demand is in line with the improvement of tourism information technology. Spiritual tourism will continuously develop due to the changes in the needs of the market.

Initially, spiritual activity was directly connected with religion, and has now shifted to the idea to something that is related with spiritual activities which include, creating comfort, pleasure and quality experience. Despite of the rapid development, it can be seen in the academic research, there are still several researchers who argue that religious and spiritual tourism as the same type of tourism.

Religious spiritual tourism requires a new mode as a form of quality tourism development so that it will organize socio-cultural life with varieties of unique customs and become a tool to increase regional income, creating job opportunities and indirectly improve Malaysians' quality of life.

Thus, there is an urgent need to integrate the religious aspect into spiritual tourism. Hence, this research aims to develop an Islamic Spiritual Tourism Model (ISToM) based on Maqasid As Shariah. 
This research aims to develop an Islamic Spiritual Tourism Model (ISToM) for the millennial generation in Malaysia.

\section{METHODOLOGY}

This study focusses on the development of Islamic Spiritual Tourism Model for the millennial generation on Malaysia with three main objectives. Design and Developmental Research (DDR) will be used in this research. There are three phases involved which are: Phase 1 needs analysis, Phase 2 model design and development and Phase 3 model evolution. In Phase 1, the researcher will distribute questionaries to 384 millennials as a sample of this research. The questionnaires will touch on question related to the millennials perceptions, knowledge and acceptance towards Islamic Spiritual Tourism.

After gather this data, phase 2 will start where researchers will start to develop the component of Islamic Spiritual Tourism based on five main components in Maqasid As Shariah.

The data will be collected from dalil Quran, hadith and Muslim scholar works. After the component of model is develop then researchers will analyse the data using fuzzy Delphi. This analysis requires researchers to request confirmation from 10 experts to confirm on the model. The experts will be selected via authoritative sampling technique among those who are coming from six tourism stakeholder (Islamic Tourism Centers, Travel Agents, decision makers) and four academicians.

Table 1: Phases in the development of ISToM

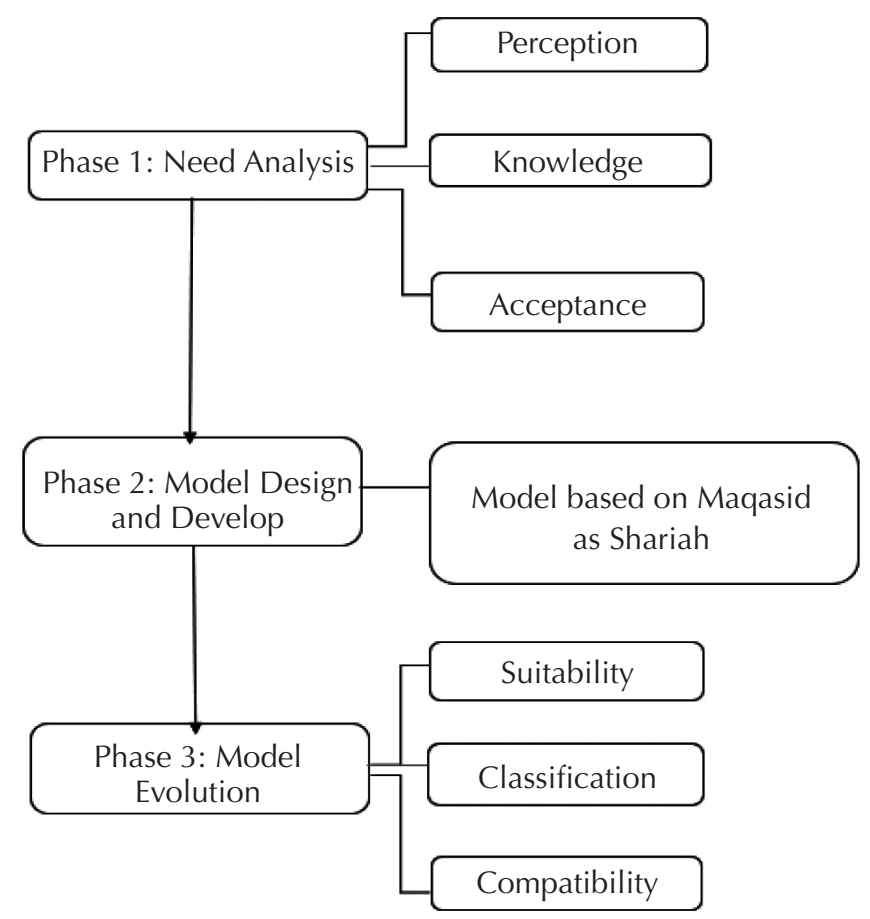

\section{CONCLUSION}

It is hoped that this model will improve the planning activity for the travel operators and organizations, giving them the opportunity to access a new spiritual tourism segment that could boost the overall tourist numbers in the future. Furthermore, it will lead to better employment opportunities, provide quality experiences to tourists or travelers, respect local communities, preserve the Malaysian tourism industry, and bring about many other benefits. 
The correct method of commercialisation will stimulate the spiritual tourism economic development. Spiritual tourism requires a new mode as a form of quality tourism development so that it will organize socio cultural life with varieties of unique customs and become a tool to increase regional income, create job opportunities and indirectly improve the Malaysian quality of life.

Last but not least, it contributes to the existing knowledge about values and provide implications for developing spiritual tourism sustainably.

\section{CONTRIBUTION/PRACTICAL IMPLICATIONS}

This will influence the planning activity for the travel operators and organisations, giving them the scope to access a new spiritual tourism segment that could increase the overall number of tourists in the future.

Furthermore, this development will lead to better employment opportunities, provide quality experiences to tourists or travellers, respect local communities, preserve Malaysian Tourism Industry, and bring many other benefits.

Spiritual tourism requires a new mode as a form of quality tourism development so that it will organise socio-cultural life with varieties of unique customs and become a tool to increase regional income, create job opportunities and indirectly improve Malaysian quality of life. The correct method of commercialisation will stimulate the spiritual tourism economic development.

\section{REFERENCES}

Haq, F. M., \& Medhekar, A. (2020). The rise of spiritual tourism in South Asia as Business Internationalization. Journal of Management and Research, 7(1), 52-78.

Mukherjee, S., Bhattacharjee, S., \& Singha, S. (2020). Religious to spiritual tourism - An era of paradigm shift in India. Journal of Xi'an University of Architecture \& Technology, XII(II), 427-441.

Sirirat, P. (2019). Spiritual tourism as a tool for sustainability: A case study of Nakhon Phanom province, Thailand. International Journal of Religious Tourism and Pilgrimage, 7(3), 97-111. 